\title{
Supply Chain of Vegetable Commodities in Boyolali, Central Java
}

\author{
Aflit Nuryulia Praswati ${ }^{1}$, Bayu Dian Aji ${ }^{2}$ \\ Faculty of Economics and Business, Universitas Muhammadiyah Surakarta \\ Corresponding e-mail : ${ }^{1}$ anp122@ums.ac.id, ${ }^{2}$ bayu.dian30@gmail.com
}

\begin{abstract}
Vegetables are an important commodity for a country. Vegetable prices contribute to the inflation rate in some regions of Indonesia. Inflation and deflation are inseparable from the type of food and vegetable groups because the majority of the population have jobs as vegetable farmers. SeloBoyolali is a vegetable producing area, but currently it can not meet the needs of its own region. Supply of vegetables began to decrease due to pests and vegetable turnover into tobacco. If the delivery of vegetables is hampered there will be a scarcity of vegetables that result in price increases. The length of the distribution channel has a negative impact, namely the price of commodities set by the middlemen or traders who distribute vegetables from the producers. So sometimes local farmers do not have bargaining power on the price determination of vegetables. This study aims to analyze the pattern of price formation and vegetable distribution in Boyolali. The analytical framework used in this research is supply chain management framework. The method used in this research is quantitative and qualitative. Respondents from this study were 101 people. Farmers in the slopes of Mount Merapi and Merbabu such as the villages of Selo, Cepogo, Ampel, and Musuk. These villages became the basis of vegetable production sufficient for Boyolali area and became the main supplier of vegetables in Soloraya and Yogyakarta. Modern channels are traders who channel the modern market such as supermarkets, supermarkets and other modern shops. In this channel, only goods that have the best quality and the price can be 2-5 times the price in the traditional market. Traditional channels are traders who are in the traditional market, in this channel the incoming goods are not limited and all kinds of goods can enter with all the existing quality from best to worst mixed here. However, the prices that apply here are also not as high as the modern market. Mixed channels are widely used by middlemen or farmers. Here the goods that have good quality are separated and then sold to the modern market in hopes of getting more profit. While the goods with the second quality go to the traditional distribution channels are cheaper. At this level the price of vegetables is strongly influenced by the quality of vegetables, the amount of vegetable availability and the amount of vegetable demand itself.
\end{abstract}

Keyword: component; supply chain, price, distribution, commodity.

Submited : 2 Desember 2017

\section{PENDAHULUAN}

Price research is closely related to inflation, macroeconomic stabilization as well as aspects of commodity distribution. Changes in commodity prices contributed substantially to the Consumer Price Index

\section{Revised : 14 Januari $2018 \quad$ Published : 28 Maret 2018}

(Inamura et al., 2011). Chen et al., (2008) states that commodity prices could have an indirect impact on exchange rates. The study of commodity and price distributions relates to the time of delivery to consumers, consumer buying intentions, price quality and fairness perceptions of 
the level of profit of each party in a supply chain (Xia, et al., 2004; Chandrashekaran, 2005). Vegetables are an important commodity, whose prices contribute to the inflation rate in some regions of Indonesia. Boyolali in february year 2016 experienced deflation of $0.09 \%$ (Solopos, 2016). Research on the organization of holticultural value chains in developed economies is extremely scarce although organizational design is often a major determinant of competitiveness (Kayser et al., 2015). Foodstuffs and vegetables groups are the main components affecting deflation. The deflation figure has a Consumer Price Index of 120.35. Inflation and deflation are inseparable from the type of food and vegetable groups because the majority of the population have jobs as vegetable farmers.

People's awareness to consume vegetables is increasing. This should be accompanied by affordable vegetable prices. Selo Boyolali is a vegetable producing area, but currently it can not meet the needs of its own region. Supply of vegetables began to decrease due to pests and vegetable turnover into tobacco. To meet the needs of vegetables imported from Tawangmangu karanganyar and Ketep Magelang. If the delivery of vegetables is hampered there will be a scarcity of vegetables that result in price increases. The length of the distribution channel has a negative impact, namely the price of commodities set by the middlemen or traders who distribute vegetables from the producers. So sometimes local farmers do not have bargaining power on the price determination of vegetables. The purpose of this study is to analyze and suck the chain of distribution and marketing of vegetable products in the area of Boyolali Central Java. The analytical framework used in this research is supply chain management framework.
This study aims to analyze the pattern of price formation and vegetable distribution in Boyolali. The analytical framework used in this research is supply chain management framework. The research design used in this research is the design of quantitative survey and qualitative research in depth interview. Survey research design is used to analyze data about cost structure, profitability and delivery time of each institution in supply chain. Qualitative design uses in depth interview that is to analyze the behavior of intermediary institutions in the supply chain of vegetables. The population of this study are all institutions involved in the supply chain of vegetables, consisting of: farmers, collectors, wholesalers, modern and traditional retail traders, business consumers and end consumers in the region Boyolali. This research uses combination sampling method from purposive random sampling. The special characteristics of the respondents are they are farmers, traders, distributors and business consumers with medium to large business scale. Determination of respondents as resource persons in depth interviews by using snow ball sampling ie one key respondents provide information about other key respondents in one supply chain path.The variables measured in this research are selling price at each distribution level.

\section{METHOD}

\section{A. Supply Chain Management}

Supply Chain Management (SCM) is a set of approaches used to integrate suppliers, entrepreneurs, warehouses and other storage areas efficiently, so that products can be produced and distributed with the right quantity, on-site and at the right time to minimize costsand satisfy customer needs (Simchi-Levi, et al., 2003).Supply chain as a form of industrial 
organization in which buyers and sellers are separated by time and geographic area, can add and accumulate value progressively, as the product moves from one link to another (Hughes, 1994, Fearne, 1996, Handfield \& Nichols, 1999).

The supply chain basically accommodates (1) physical movement / product from producer to consumer, (2) transfer of money / payment, credit and working capital from consumer to producer, (3) technology dissemination between producer, packer and processor, (4) Ownership rights from producers to processors and eventually to marketers, and (5) feedback flows concerning consumer demand information and preferences from retailers to producers (Cooper et al., 1997).Supply chain management is the process of planning, designing and controlling the flow of information and materials in a supply chain to meet consumer needs in the most efficient way (Schroeder, 2000; Zachariassen and van Liempd, 2010).

Supply chain management frameworks can provide information about business actors in the vegetable distribution chain. Vidalakis et al., (2011) explains the role and function of the intermediary institution in a supply chain management can be identified so as to obtain information on profit sharing. Wong and Wong (2007) stated that the key word of supply chain performance is efficiency that is the ratio between the cost incurred by each agency in the supply chain with profit and delivery time.

\section{B. Members of Supply Chain \\ Management}

SCM implementation involves identifying members of the supply chain with whom they relate, what processes need to be associated with each core member and what type of incorporation is applied to each process of the relationship.
The goal is to maximize competition and profit for the company and all its members, including end customers. Supply chain members include all corporations and organizations dealing with core companies either directly or indirectly through suppliers and customers from point of origin to point consumption.

Primary members are all companies or business unit strategies that actually carry out operational and managerial activities in business processes designed to produce a specific outcome for the customer or the market. Secondary members are companies that provide resources, knowledge, utility or assets for the primary members. Through the definition of primary members and secondary members is obtained the sense of the point of origin of the supply chain is the point where there is no primary supplier. All suppliers are secondary members, while the point consumption is the point where there are no major customers (Miranda and Tunggal, 2005).

\section{Vegetables Supply Chain}

Based on Susenas BPS 2017, there are 97,29 percent of the population of Indonesia consuming vegetables. The increasing trend of vegetable consumption has made the improvement of the health condition of Indonesian society. There was a decrease in the number of people complaining of illness from 2015 by $30.35 \%$ to $28.53 \%$.

Each farmer uses a variety of marketing channels. Therefore, many combine the commercializations through the wholesale market and regional supermarkets with booth at a farmer's market and direct marketing on the farm (Behr and Niehues, 2009). There is many small and medium producers are members of farmer organizations, which pool the quantities delivered by individual farmers and sell 
them to processors, wholesalers or retailers (Kayser et al., 2016)

This survey was conducted on members of the Boyolali vegetable supply chain, namely farmers, collectors, wholesalers and small traders. (1) Farmers (People who work farming. (2.) Collectors / Wholesalers (The person whose job is steaming from the manufacturer directly to then sold to the final merchant or consumer.) (3.) Big Traders (Merchants who sell in large quantities and make sales to other merchants (retailers) not to the end consumer.) (4.) Small Traders (Is a merchant who sells goods directly to the end consumer and for consumption).

\section{Price Policy}

Commodity prices play an important role in economic stabilization in developing countries. Indonesia is a country with market structure that has oligopoly tendency in both commodity and industry (Kurniati and Yanfitri, 2010). This oligopoly-prone market results in the process of price formation not influenced by the mechanism of demand and supply. The pricing strategy is influenced by several things: cost structure, competition, communication strategy with consumers and marketing strategy in general (Levy et al., 2004). Oligopoly markets can encourage benefit-sharing disparities between intermediary institutions and producers. Prices at the consumer level may be higher due to the difference in information. Ferreira and Ferreira (2010) show that the oligopoly market structure can benefit those with information to take more advantage in a distribution channel.

Price is an important variable in product and commodity marketing strategy. Xu (2008) explains the policy of price discrimination not only influenced by the level of consumer income, but also the characteristics and behavior of consumers. Barsky et al. (2001) also examines the determination of price marks that can be useful for predicting consumer interest in making purchases.

\section{RESULTS AND DISCUSSION}

The survey was conducted in April 2017. April is the peak of the rainy season so it is perfect for analyzing the vegetable supply chain. In the rainy season farmers Boyolali very fond of planting these plants because of the high water needs. Types of vegetables studied were Carrot, Cabbage, Tomato, Curly Chilli, and Onion. The five types of vegetables are included in the indicators of performance measurement in Boyolali Regency in 2015. Increasing the production and productivity of vegetable horticulture in Boyolali Regency is relatively increasing from 2011 to 2015. More details can be seen in the following table:

\begin{tabular}{|l|l|l|l|l|l|}
\hline & Red & Cabbage & Chilli & Tomato & Carrot \\
& Onion & & & & \\
\hline 2011 & 24,325 & 121,104 & 121,394 & 29,062 & 118,225 \\
\hline 2012 & 30,129 & 209,479 & 288,228 & 26,81 & 92,44 \\
\hline 2013 & 22,791 & 171,701 & 238,322 & 37,427 & 252,115 \\
\hline 2014 & 30,819 & 150,208 & 292,042 & 17,580 & 139,523 \\
\hline 2015 & 104,357 & 97,487 & 319,363 & 18,335 & 160,370 \\
\hline
\end{tabular}

Table 1. increasing number of vegetable horticultural production (quintal)

The amount of vegetable horticulture production in Boyolali is relatively increasing. Red onion production increased from 22.791 quintals in 2013, 30.819 quintal in 2014 and 104.357 quintal in 2015. The amount of cabbage production declined in 2014 reaching 150.208 quintals to 97.487 quintals. This is because the farmers are still using conventional cultivation methods. The chili produced by Boyolali farmers has increased since 2013 by 238,322 quintals, 292.042 quintal (2014) and increased again 
to 319,363 quintals by 2015 . This achievement is supported by the government program of Good Agriculture Practice Field School (SL GAP) and Development Program Cabe Area APBN 2015. Since 2011 the highest production amount in 2013 is 252.115 quintal, then decreased to 139,523 quintal and rose again in 2015 as much as 160,370 quintal.

\begin{tabular}{|l|l|l|l|l|l|}
\hline & Red & Cabbage & Chilli & Tomato & Carrot \\
\hline 2011 & 106,69 & 124,72 & 50,36 & 124,2 & 124,32 \\
\hline 2012 & 118,62 & 146,391 & 25,32 & 53,20 & 124,99 \\
\hline 2013 & 64,75 & 109,83 & 100,64 & 224,11 & 143,11 \\
\hline 2014 & 66,71 & 177,13 & 105,07 & 148,35 & 168,1 \\
\hline 2015 & 109,73 & 134,84 & 124,51 & 156,71 & 152,44 \\
\hline
\end{tabular}

Table 2. increasing the number of horticultural productivity vegetables (kuintal / hectare)

The productivity of horticulture of onion, chilli and tomato vegetables is increasing every year. Cabbage and carrots slightly decreased. Whether or not a program of applying appropriate agricultural technology funded by the Revenue Budget, and Boyolali Regional Expenditure, superior seed support and farmers interest in the application of science gained into factors that affect the ups and downs of productivity of vegetable horticulture in Boyolali.

\section{A. Description of respondents}

The data collection process was conducted through a survey to farmers, collectors, wholesalers and small traders.in Boyolali.The number of respondents from this study as many as 101 people.

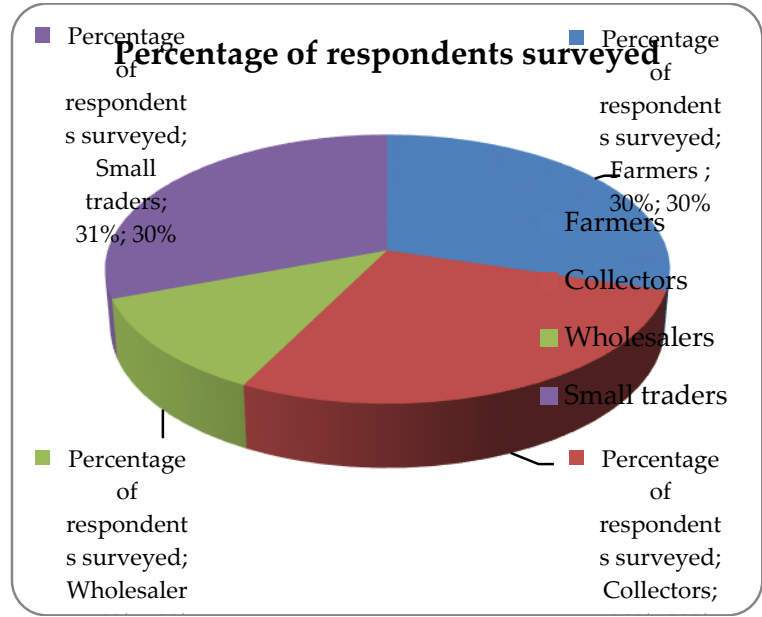

Fig. 1: Percentage of respondent surveyed in Boyolali

The composition of the respondents is $30 \%$ of farmers, $28 \%$ of collectors, $12 \%$ big traders, $30 \%$ small traders. The form of business entity of business actors in the distribution of vegetable trade in Boyolali is an individual business that does not yet have a legal entity. Many farmers cultivate their agricultural land not with employees but only do it themselves.

Farming methods of most farmers use mulch plastic to reduce plant pests that interfere with the main crop but also many do not use. Some farmers apply the management of rice fields in a modern way such as the tools used and how to cultivate it but also still many who embrace traditional agriculture. How to grow the farmers here using the intercropping system, while the types of plants are also very varied but they often do similar planting simultaneously depending on what season is happening. So sometimes the supply of certain goods in the market abundant and not accommodated resulting in the price plummeted which makes a huge loss by farmers and on the other side to make the price of the type of plants that supply slightly to soar even uncontrollable as the case of the price of chili in 2016 which mancapai Rp. 170.000 / Kg. Here the weakness of farmers is they do not 
understand the needs of the market. So that resulted in many farmers lose money when the harvest arrives. Another factor that is the biggest loss factor is pest attacks that sometimes make harvest failures reach $100 \%$ and climate change is currently very difficult to predict.

B. Scheme of distribution chain and marketing of vegetable products Boyolali

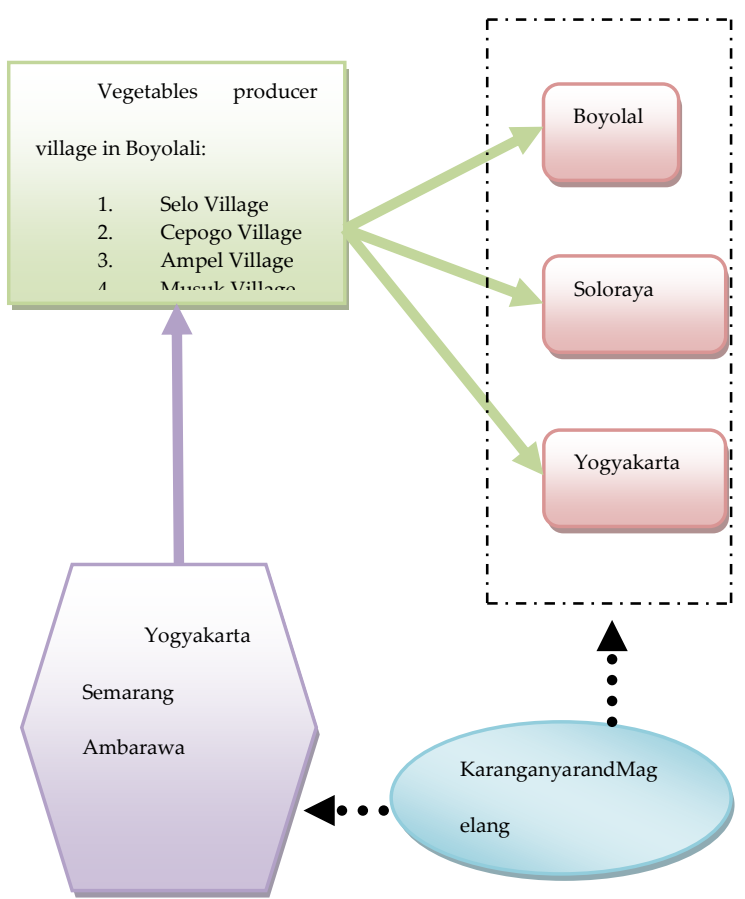

Fig. 2. Scheme of distribution chain and marketing of vegetable products Boyolali 2017

Some villages in Boyolali that produce vegetables are Selo, Cepogo, Ampel and Musuk villages. Vegetables produced to meet the needs of the community Soloraya, Yogyakarta and Boyolali own district. Some middlemen from other regions also often come to get supplies of vegetables from the four villages in Boyolali, some of which are middlemen from Yogyakarta, Ambarawa and Semarang. In addition, the fulfillment of vegetable needs is also met by farmers from the area of Karanganyar and Magelang. Types of vegetable distribution channels in Boyolali District are included in modern channel types, traditional channels and mixed ducts.
- Modern channels are traders who distribute vegetable products to modern markets such as supermarkets, supermarkets and other modern shops. In this channel the product must have the best quality. The price of the product can be 2-5 times the price in the traditional market. The products traded here have received preferential treatment such as good packing and good hygiene.

- Traditional channels are traders located in the traditional market, in this channel the vegetables that enter is not restricted, all kinds of good vegetables high to low quality. The prices that apply here are not as high as the modern market. Packing that was done was also impressed what it is and not as good as the modern market more mengepentingkan appearance and quality of good goods.

- Mixed channels, a lot of middlemen or farmers who use this channel. Here the products that have good quality are separated and then sold to the modern market in hopes of getting more profit. While the goods with the second quality go to the traditional distribution channels are cheaper. At this level the price of vegetables is strongly influenced by the quality of vegetables, the amount of vegetable availability and the amount of vegetable demand itself. The layout design of distribution center should be considered as a smart decision systems that includes the number of consumers, demand forecasting, product groups, condition of produst conservation, warehousing, transportation management etc (Demirtas and Tuzkaya, 2012).

There are only two marketing channels that are existing (Roy and Poddar, 2015; Acharya and Agarwal, 2010). The identified marketing channels are as follows: 
1. Producers $->$ Wholesaler $->$ Retailer $>$ Consumer

2. Producers $->$ Consumer

Farmers have no other options to retain the produce for future price rice or to send to distant market. They depend upon the wholesalers. A few portion of the produce are brought to market for retail purpose (Roy and Poddar, 2015). There is two ways of selling are:

1. Farm produce are disposed off from the farm gate itself through the wholesalers and

2. Selling of farm produce through retail outlets in the local/nearby markets.

Sangeetha and Banumathy (2011), the identified marketing channelsfor tomato and brinjal were:

Channel I Producer - Commission agent cumwholesaller - Retailer - Consumer

Channel II Producer - Commission agent cum wholesaller - Consumer

Channel III Producer - Consumer

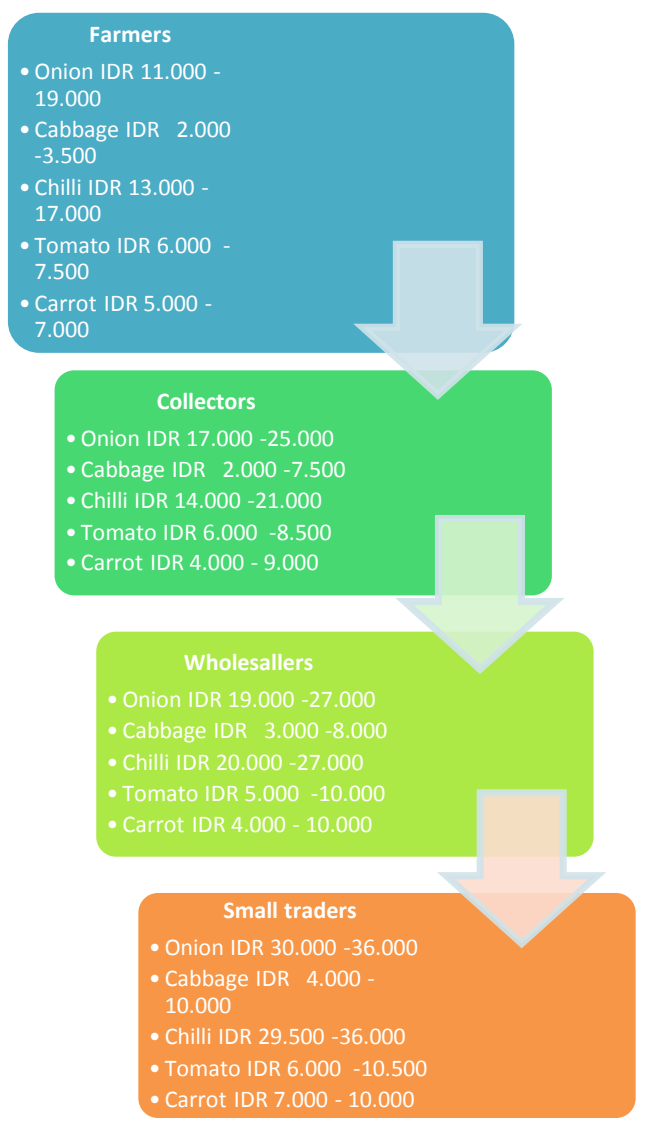

Fig. 3. Vegetable Commodity Price Flow in Boyolali 2017
The average price of local farmers ranges from IDR $11,000-19,000 / \mathrm{kg}$ for onions, IDR. 2.000-3.500 / kg for cabbage, chilli IDR 13.000-17.000, tomato IDR 6.000$7.500 / \mathrm{kg}$ and carrots IDR 5,000-7.000 / kg. The price is determined by the collectors who directly take the harvest from the farmers, while the farmers themselves can not determine the selling price. To produce vegetables farmers need the cost of seed procurement for 1 harvest period of IDR $3,535,308$. The average cost of land preparation is IDR 3,826,154. The cost of fertilizer in one harvest season is 2,252,308. The cost of anti-pests drugs is 693,846 every harvest season.

The collectors set prices according to the vegetable supply in the market that is at harvest time, the average lowest price is around IDR $17.000 / \mathrm{kg}$ for onions, IDR $2.000 / \mathrm{kg}$ for cabbage, chili per kilogram IDR 14,000, tomatoes IDR 6,000 and carrots IDR $4,000 / \mathrm{kg}$. While at the time of the rare chili on the market, the collectors set the highest price to the farmer IDR 25.000 / $\mathrm{kg}$ for onions, IDR 7,500 / $\mathrm{kg}$ for cabbage, chili per kilogram IDR 21.000, tomatoes IDR 8.500 and carrots IDR $9.500 / \mathrm{kg}$.

The wholesalers set prices according to the vegetable supply in the market that is at harvest time, the average lowest price is around IDR $19.000 / \mathrm{kg}$ for onions, IDR 3.000 / kg for cabbage, chili per kilogram IDR 20,000, tomatoes IDR 5,000 and carrots IDR $4,000 / \mathrm{kg}$. While at the time of the rare vegetables on the market, the collectors set the highest price to the farmer IDR $27.000 / \mathrm{kg}$ for onions, IDR 8.000 / kg for cabbage, chili per kilogram IDR 27.000, tomatoes IDR 10.000 and carrots IDR 10.000 / kg.

The small traders set prices according to the vegetable supply in the market that is at harvest time, the average lowest price is around IDR $30.000 / \mathrm{kg}$ for onions, IDR 4.000 / kg for cabbage, chili per kilogram 
IDR 29.500, tomatoes IDR 5.500 and carrots IDR $7,000 / \mathrm{kg}$. While at the time of the rare chili on the market, the collectors set the highest price to the farmer IDR 36.000 / $\mathrm{kg}$ for onions, IDR 10.000 / kg for cabbage, chili per kilogram IDR 36.000, tomatoes IDR 10.500 and carrots IDR $10.000 / \mathrm{kg}$.

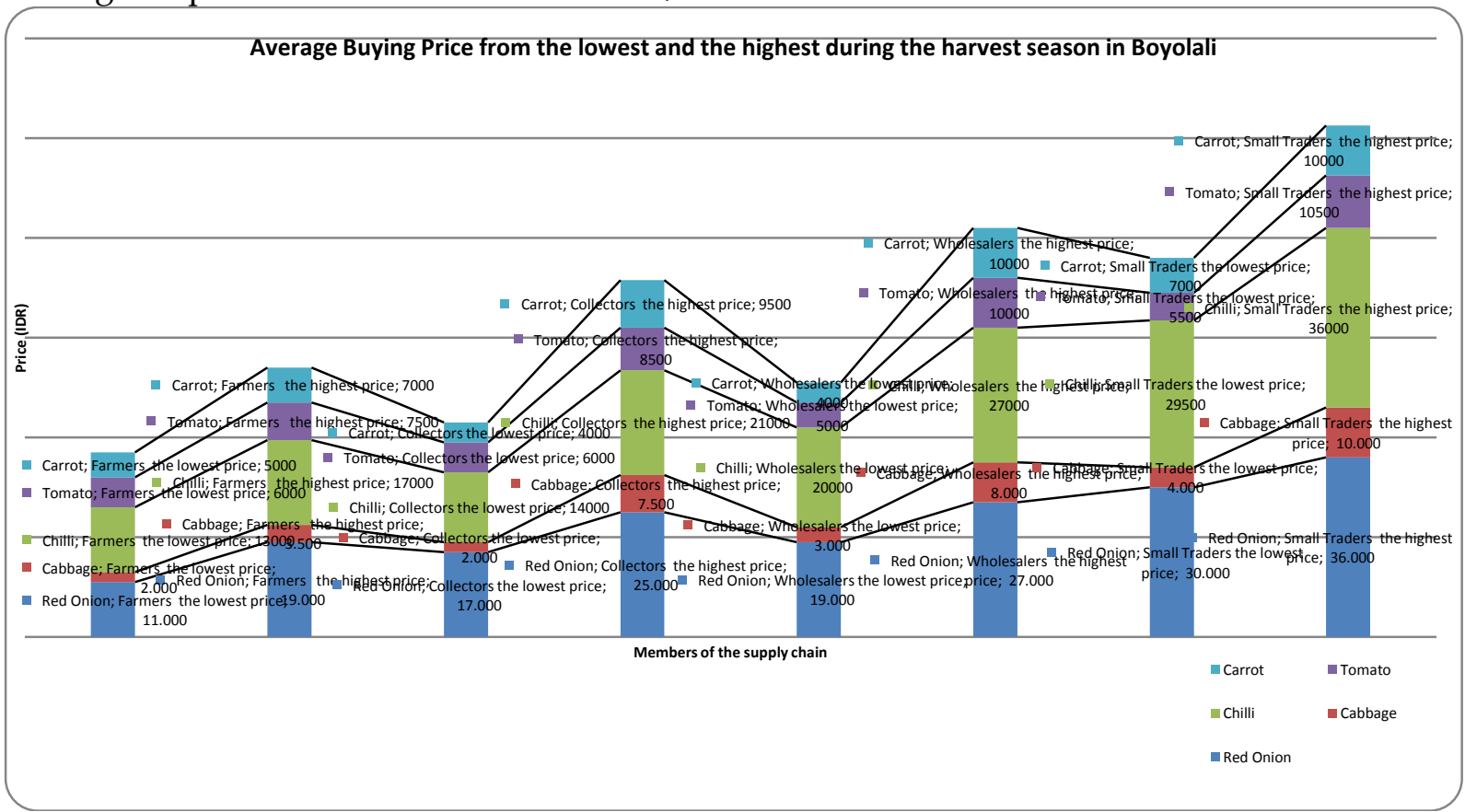

Fig. 4. Average Buying Price from the lowest and the highest during the harvest season in Boyolali

Farmers in the slopes of Mount Merapi and Merbabu such as the villages of Selo, Cepogo, Ampel, and Musuk. These villages became the basis of vegetable production sufficient for Boyolali area and became the main supplier of vegetables in Soloraya and Yogyakarta. Modern channels are traders who channel the modern market such as supermarkets, supermarkets and other modern shops. In this channel, only goods that have the best quality and the price can be 2-5 times the price in the traditional market. Traditional channels are traders who are in the traditional market, in this channel the incoming goods are not limited and all kinds of goods can enter with all the existing quality from best to worst mixed here. However, the prices that apply here are also not as high as the modern market. Mixed channels are widely used by middlemen or farmers. Here the goods that have good quality are separated and then sold to the modern market in hopes of getting more profit. While the goods with the second quality go to the traditional distribution channels are cheaper. At this level the price of vegetables is strongly influenced by the quality of vegetables, the amount of vegetable availability and the amount of vegetable demand itself.

\section{DAFTAR PUSTAKA}

Chen, Yu-Chin and Rogoff, Kenneth and Rossi, Barbara, Can exchange rates forecast commodity prices? (June 29, 2008). Economic Research Initiatives at Duke (ERID) Working Paper No. 1.68

Xia, L., Monroe., K.B and Cox, J. L. "The price is unfair! A conceptual framework of price fairness perceptions.' Journal of Marketing. 68 (October) 2004 
Demirtas, Nurgul and Tuzkaya, Umut R. "Strategic planning of layout of the distribution center: an approach for fruits and vegetables hall". Elsefier, Procedia Social and Behavioral Sciences 58. Pp. 159-168. 2012.

Simchi-Levi, D., P. Kaminsky and E. Simchi-Levi. "Designing and managing the supply chain", pp. 15-165. New Delhi: Irwin McGrawHill Companies, 2003

Ting Xu."Heterogeneity in housing attribute prices", International Journal of Housing Markets and Analysis Vol. 1 No. 2, pp. 166-181. 2008.

Fearne, A.. Editorial Note. Supply chain management, Vol. 1, No. 1, pp.34.1996

Schroeder, R. G., Bates, K. A., \& Junttila, M. A. "A resource-based view of manufacturing strategy and the relationship to manufacturing performance". Strategic Management Journal, 23(3), 105117.2002

Vidalakis, C, Tookey, J E and Sommerville, $\mathrm{J}$ "The Logistics of construction supply chains: The builders' merchant perspective." Engineering Construction \& Architectural Management, 18(1), 66-81. 2011.

Inamura, Y, Kimata, T , Kimura, T, Muto, $\mathrm{T}$, "Recent surge in global commodity prices, impact of financialization of commodities and globally accommodative monetary conditions," Bank of Japan Review,March 2011
Wong, W.P. and Wong, K.Y., "A review on benchmarking of supply chain performance measures", Benchmarking: An International Journal, Vol. 15 No. 1. 2007

Kurniati, Yanti dan Yanfitri. "Dinamika industrimanufaktur dan respon terhadap siklus bisnis. Buletin Ekonomi Moneter dan Perbankan, Oktober 2010, pp. 135-168, Jakarta, 2010

Levy M., and Weitz A. Barton, Retailing Management, Fifth Edition, Mc Graw Hill, Irwin, New York. USA. 2004.

F.A. Ferreira, and F. Ferreira, "Environmental policies in an international mixed duopoly," in Applications of Mathematics in Engineering and Economics, edited by George Venkov et al., AIP Conference Proceedings 1184, American Institute of Physics, New York, 269-276. 2010.

Barsky, R.B., and Kilian, L. "Do we really know that oil caused the great stagflation? A monetary alternative." In B. Bernanke and K. Rogoff (ed.s), NBER Macroeconomics Annual 2001, May 2002, pp. 137-183.2002.

Acharya, S.S and Agarwal, N. L. "Agricultural marketing in India (Book). Oxford and IBH Publication Company, New Delhi. 2010.

Sangeetha, R and Banumanthy, "An economic analysis of marketing of major vegetables in Cuddalore district", International Journal of 
Curretnt Research. Vol. 3. Issue 4. Pp 309-312. April 2011

Roy, Tuhin Narayan and Poddar, Somnath, " Economic analysis of hybrid vegetables cultivation by marginal farmers in Chochbehar district of West Bengal" Agricultural Science research Journal 5(7); pp. 111-117, July 2015.

Pengukuran kinerja kabupaten boyolali 2015 